\title{
Does the Cascade Wolf Survive?
}

\author{
Robert Pisano
}

The Cascade wolf Canis lupus fuscus is extinct in the USA. But it may survive in Canada, in the coastal forests of British Columbia, the northernmost part of its original range. But British Columbia gives this highly endangered subspecies no special protection. Over-hunting and hybridisation with neighbouring wolf subspecies and domestic dogs are the chief threats. The author reviews wolf management in coastal British Columbia and suggests changes that would improve the Cascade wolf's prospects, including complete protection of all wolves on wilderness islands where it may survive.

The grey or timber wolf Canis lupus, ranged over most of North America virtually undisturbed until the European settlers arrived.l To them, it was a competitor for game and a marauder of domestic stock, and numbers declined dramatically; ${ }^{15}$ habitat too was inevitably destroyed. As a result 15 of the 27 currently ricognised subspecies of North American gray and red wolves are either extinct or highly endangered.

Gray wolves are the largest wild canid. In size, weight, pelage and colour they vary considerably among, and often within, subspecies, but generally adult males are between 5 and 6.5 feet from the front of the snout to the tip of the tail, weigh between 45 and 175 pounds, and are grizzled grey with a range from black to nearly pure white.

Today four grey wolf subspecies are protected as distinct races: the northern Rocky Mountain wolf C.l. irremotus, the Vancouver Island wolf C.l. crassodon, the Mexican wolf C.l. baileyi and, within its US range only, the eastern timber wolf C.l. lycaon. The Cascade wolf C.l. fuscus has no protection, and its status is far from clear.

The Cascade wolf originally occurred throughout the dense forests of the north-western United States and coastal British Columbia. Described as dark 'cinnamon' or 'cinnamon-buffy' in colour with the entire back 'profusely overlaid with black',15 it was widely known as the 'brown wolf', or, among the early settlers of Washington's Olympic peninsula, as 'red legs'. ${ }^{2}$ A black colour phase was common, but the pale grey phase frequently seen in other subspecies was unknown. ${ }^{9}$ A small to medium-sized wolf, fuscus is comparable to youngi of Utah, irremotus of Montana and crassodon of Vancouver Island, but is distinctly smaller than columbianus of interior British Columbia, 15 and the skull, rostrum and nasals are shorter than in neighbouring forms. By the early 1920s it was extinct in California, Nevada and Washington, and the last verified specimen in Oregon was taken in 1946. If there are remnant populations, it is assumed that they will be in coastal British Columbia.

\section{Wolf Management in British Columbia}

By the early 1900 s the gray wolf was declining throughout most of southern British Columbia.13 A government bounty started in 1909 continued well into the 1950s, but whereas most of the human population was concentrated in the south, most of the bounties collected were for wolves taken in the northern half 
of the Province. By the 1940s they averaged about 1200 annually, but after 1949 declined steadily. This was probably because of a provincial control programme started in 1947, the most ambitious in all Canada, and the result of pressure from stockmen, trappers and guides. Poison baits, such as compound 1080 (sodium flouracetate), were scattered throughout most of the wolf range in the province. 1080 works slowly and most of it was dropped over remote and inaccessible places, so that many more wolves are believed to have been killed than were accounted for. By the 1950s 'the wolf was exterminated in most areas of the province', 5 a 'clear case of mismanagement'. 14 After 1958 control decreased; wolves increased slowly and gradually repopulated most areas from which they had been eliminated. It may have been during this period that the subspecies became redistributed. 5

In 1966 the wolf was classified as a 'big game' animal, and in 1967 the Predator Control Division was disbanded - a reflection of changing attitudes. At first game status did little for the wolf except to improve its public image, and kills for 1966-1969 were not even listed in the Tables of Game Harvests in the annual reports of the Fish and Wildlife Branch (FWB). ${ }^{14}$ But both management and records improved, and the Branch released figures for wolves taken in the 1970-1971 season: 419 by resident hunters, 64 by non-residents, 52 by trappers and approximately 15 by control. ${ }^{14}$ Also in 1971, the Department of Recreation and Conservation, of which the Fish and Wildlife Branch is a part, announced its official predator control policy as being one of 'minimal control'.

'This means that control is not directed at predators in general, but at specific animals threatening human safety or legitimate human enterprise. Where wildlife is the prey involved, predator control is not practised. This general policy is applied throughout the province, including game sanctuaries and provincial parks. No bounties are paid on wildlife species by the provincial government. . . Predator control is an activity of our Conservation Officer staff. Control is handled by each region and is the result of discussion between the Regional Supervision and Regional Wildlife Biologist. . .'

(quoted in Theberge, p 95.14)

Theberge commented, 'With this policy, game status for wolves, and complete protection in all Class A and Class B provincial parks, British Columbia stands as a model for the rest of Canada. There are some problems, to be sure, such as illegal poisoning by sorne guides due to lack of enforcement, and protection not granted in all classes of parks. But these are of minor importance.' But the lack of considerations for subspecies in mainland management plans (the Vancouver Islands subspecies is discretely managed) may be crucial. In 1977 Halliday, for example, noted that since the recovery of wolf populations from their low point in the 1950 s, columbianus had become dominant; ${ }^{5}$ Hebert noted that separation between crassodon, columbianus and fuscus in the mainland portion of Game Management Region 1 was poor, ${ }^{7}$ and Mitchell submitted that management in Region 5 had not been concerned with subspecies. ${ }^{12}$

\section{Geographic Scope}

The Cascade wolf historically inhabited the coastal forests of the Cascade and Coast Mountains, and west to all the coastal islands except Vancouver Island and the Queen Charlottes. ${ }^{9}$ The northern limits have never been determined ${ }^{9,15}$ but are assumed to have been the limit of the coastal forest, 250 miles $(400 \mathrm{~km})$ north 


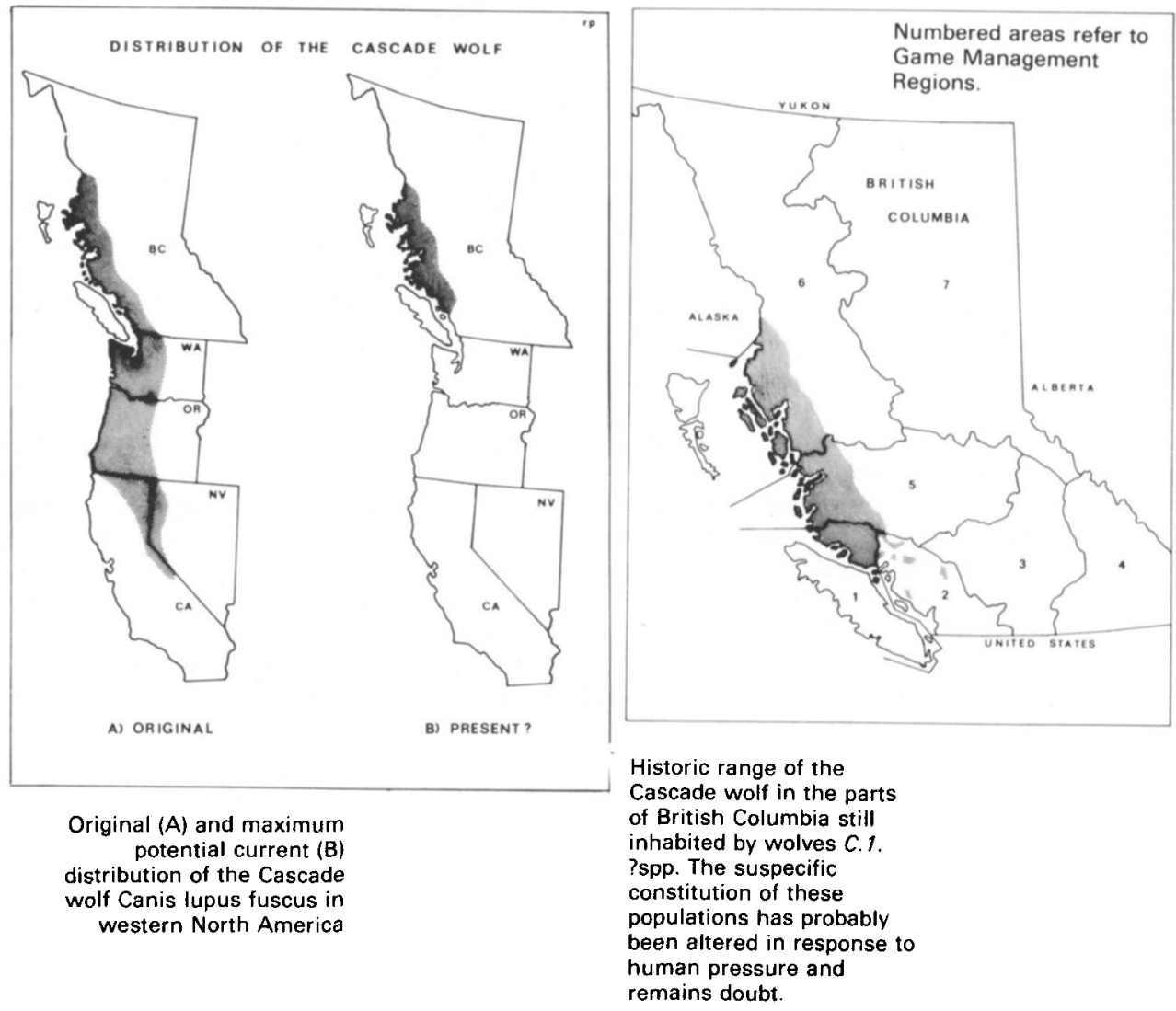

of the most northerly fuscus record. ${ }^{4}$ Most of the Management Units in these Regions, apart from those in the southern half of Region 2, still harbour significant populations, and the bag limits, seasons, and other hunting regulations discussed below were in effect in 1977 and 1978.11 Some areas within these units are closed to hunting and/or trapping, but however well they might serve to protect localised fauna and flora, it cannot be assumed that they are large enough to contain such a mobile and wide-ranging animal as the wolf.

\section{Region 1}

Region 1 includes the entire historic range of the Vancouver Island wolf, together with a small portion of fuscus range on the islands between Vancouver and the mainland, and along the mainland coast. Hebert reported that wolves were present in every major drainage here but that not only was subspecific separation poor between crassodon, columbianus and fuscus but information regarding fuscus in particular was meagre and mostly unsubstantiated, though attempts were being made to improve collection and taxonomy. ${ }^{7}$

On Vancouver Island subspecific management is practised. Crassodon is recognised in Appendix II of the 1973 Convention on International Trade in Endangered Species of Wild Fauna and Flora (CITES), and there is no open 
season for wolves in the southern half of the island; in the northern half it lasts only five months, with a bag limit of one animal per hunter. Furthermore, the skulls and hides of all wolves taken on Vancouver Island must be submitted to a District Conservation Officer for examination. Thus pressure on crassodon populations is carefully monitored, and management practices reflect sound taxonomy. In contrast, there is no close season for wolves in the coastal island and mainland parts of Region 1, and the bag limit is three per hunter, without any compulsory reporting for examination. Consequently, if fuscus occurs, the current bag limit and liberal season may constitute, in the words of Appendix II of the CITES treaty, 'utilisation incompatible with their survival'. 8

\section{Region 2}

All Management Units in Region 2 fall within the historic range of fuscus. This region extends from the international border north to Loughborough Inlet and Mt Waddington, and from the crest of the Cascade and Coast Ranges west to the mainland coast. Permanent wolf populations are currently confined to the head of Bute Inlet and to the bottomlands of the Homathko, Southgate, Orford and Toba river systems; occasional wolf populations are reported near Pemberton and on the Sechelt Peninsula. ${ }^{3}$ There is no close season for wolves in the northern half of Region 2, the bag limit is three animals, and there is no compulsory examination. The southern half has no open season but apparently no wolves either.

\section{Region 5}

Region 5 extends from Cape Caution and the Don Peninsula along the coast and east to the Cariboo Mountains approaching the border with Alberta. The area west of the Coast Range Crest includes part of the original range of fuscus. In 1977, H.B. Mitchell of the FWB wrote:

'In the management of Region 5 we have not concerned ourselves with the subspecies of wolves, they are just "wolves". Our concerns are the numbers, distribution, track numbers and their effect on domestic livestock. Our concern has been how to balance wolf packs with livestock predation so the problem of what subspecies we are dealing with doesn't enter into our management. . . our wolf numbers are probably in the neighbourhood of 50.70 animals in about 10 packs of more than one animal.'12

He did not specify what proportion of these animals inhabited the area west of the Coast Range Crest, but if distribution was uniform throughout the Region, this number would suggest 20 or 30 wolves. There is no close season for wolves in this Region, except in a Management Unit well within the range of columbianus; the bag limit is three animals, with no mandatory inspection.

\section{Region 6}

D.F. Hatler of the FWB, who reported in 1977 that viable wolf populations occurred in all Management Units of Region 6 except the Queen Charlotte Islands, wrote:

'If there is such a thing as pure Canis lupus fuscus, it will probably occur on some of our larger north coastal islands such as Porcher, Pitt, Banks, Aristazabel, and Price Islands in Region 6... Within the past decade, wolves have attained high numbers 
throughout northern BC including the coast. . I suspect that population pressures have been high enough in many areas to promote the kind of dispersal rates which would lead to dilution of 'pure' gene pools. While we often had reports of wolves on the islands named above, we have little opportunity to contact them. There is some chance for hybridisation with dogs on Porcher Island, but little likelihood that this occurs in any of the others, which are largely uninhabited wilderness. I do not know of any specimen material having been taken from these areas in recent years.' 6

The Region's 1977/78 hunting season was August 1 to April 30, with a bag limit of three animals, giving a close season for the pup-rearing period. These facts suggest that the prospect of discovering intact fuscus population is greater in this region than in any other, although much of the area lies beyond the northernmost record of the subspecies listed by Hall and Kelson (1959). 4 Because the historic ranges of fuscus, columbianus and ligoni converged in this region, subspecific intergradation may even have been common here under primeval conditions. In any event, even here there are neither subspecific management plans nor reasonable documentation for the existence of fuscus.

\section{Conclusions}

It can be safely assumed that, throughout most of its former range, the Cascade wolf is extinct, and that nowhere within its potential current range is wolf management consistent with present knowledge of the subspecies. Whether or not the liberal hunting seasons and bag limits, which may be sound for the species as a whole in British Columbia, are in fact detrimental to any remnant fuscus populations cannot be determined without more precise taxonomic appraisal of wolves in this area, but it seems possible that a subspecies which could be built up again is being over-harvested. Combined with other limiting factors to which depressed populations are susceptible, such as genetic swamping by closely related wolf subspecies, and dogs, this could ensure the extinction of the Cascade wolf. Official concern over its fate has been small, if not entirely lacking. Equally little is known about the status of the Vancouver Island and northern Rocky Mountain wolves, yet in British Columbia conscientious efforts have been made to protect these subspecies. Good conservation suggests that we should maintain a broad margin for uncertainty.

\section{Recommendations}

1. Official designation of the Cascade wolf as a severely endangered subspecies.

2. Complete protection of the entire species within insular areas of suspected Cascade wolf concentration - most likely the large wilderness coastal islands of Game Regions 5 and 6.

3. Reduction of bag limit, restriction of open season, and compulsory reporting of all wolf material (skulls and pelts) taken by sport hunters and trappers in mainland management units west of the Coast Range crest; all material reported should be routinely examined by Conservation Officers for taxonomic assessment.

4. Consideration to reintroducing the Cascade wolf to its former range in the United States in areas deemed ecologically suitable. Although this is not a new 
proposal, it has not yet been suggested from the standpoint of a subspecies recovery programme, in this case to re-establish a wild population of fuscus in an area far removed from competing subspecies and hybrids.

\section{Acknowledgments}

The author wishes to express his gratitude to D.R. Halladay, and to D.R. Forbes, D.F. Hatler, D. Hebert, and H.B. Mitchell, of the British Columbia Fish and Wildlife Branch, for expert opinions and much unpublished information regarding the possible status of the Cascade wolf in areas under their jurisdictions. Particular gratitude is due to Ronald $M$. Nowak, of the US Office of Endangered Species, for kindly providing and consenting to the use of his unpublished research and for valuable advice. Earlier drafts of the manuscript were critically reviewed by Professor Richard D. Taber, of the Department of Wildlife Science at the University of Washington, and Mr Nick Carter, Research and Information Officer of the I-ondon Field Office of the International Society for the Protection of Animals; the final version has been greatly improved in response to their comments and suggestions.

\section{References}

1. DAGG, A.I. 1974. Canadian Wildlife and Man. McClelland and Stewart, Toronto. $192 \mathrm{pp}$.

2. DRATCH, P., B. JOHNSON, I. I.EIGH, D. I.EVKOY, D. MII,NE, R. READ, R. SEIKIRK and C. SWANBERG 1975. A Case Study for Species Reintroduction: the wolf in Olympic National Park, Washington. The Evergreen State College, Washington. $82 \mathrm{pp}$.

3. FORBES, R.D. 1977. In litt. Fish and Wildlife Branch, 4240 Manor Street, Burnaby, British Columbia V5G 1 B2.

4. HAIL, E.R., and K.R. KEISON 1959. The Mammals of North America. The Ronald Press, New York. 1083 pp.

5. HAI,IADAY, D.R. 1977. In litt. Fish and Wildlife Branch, 400, 1019 Wharf Street, Victoria, British Columbia V8W $2 Z 1$.

6. HATI.ER, D.F. 1977. In litt. Fish and Wildlife Branch, PO Box 3250, Smithers, British Columbia V0J 2N0.

7. HEBERT, D. 1977. In litt. Fish and Wildlife Branch, 324 Terminal Avenue, Nanaimo, British Columbia V9R 5C8.

8. IUCN 1973. Convention on International Trade in Endangered Species of Wild Fauna and Flora. Special Supplement to IUCN Bulletin 4 (3), March 1973.

9. McTAGGART COWAN, I. and C.J. GUIJET 1975. The Mammals of British Columbia. British Columbia Provincial Museum, Victoria. $414 \mathrm{pp}$.

10. MECH, I..D. 1974. Canis lupus. Mammalian Species, No. 37: 1-6.

11. MINISTRY OF RECREATION AND CONSERVATION 1977. British Columbia Hunting Regulations Synopsis 1977-1978. Fish and Wildlife Branch, 1019 Wharf Street, Victoria, British Columbia V8W $2 Z 1$.

12. MITCHEI.I, H.B. 1977. In litt. Fish and Wildlife Branch, 540 Borland Street, Williams Lake, British Columbia V2G 1 R8.

13. NOWAK, R.M. 1974. The Grey Wolf in North America: a preliminary report. Ms., $252 \mathrm{pp}$.

14. THEBERGE, J.B. 1975. Wolf management in Canada through a decade of change. In: Pimlott, D.H. (ed.), Wolves. Proceedings of the First Working Meeting of Wolf Specialists and of the First International Conference on the Conservation of the Wolf. IUCN, 1110 Morges, Switzerland.

15. YOUNG, S.P., and E.A. GOIDMAN 1944. The Wolves of North America. Dover Publications, New York. 636 pp. 